\title{
MANHAJ TAFSIR BERORIENTASI FIQH
}

\author{
Ahmadi Husain \\ Sekolah Tinggi Ilmu Tarbiyah (STIT) Syamsul Ma’arif Bontang \\ Email : ahmadihusain88@gmail.com \\ Muh. Ilham Usman \\ Sekolah Tinggi Agama Islam Negeri (STAIN) Majene \\ Email : ilhamusman@stainmajene.ac.id
}

\begin{abstract}
Abstrak
Tulisan ini menyajikan hasil penelitian tentang manhaj tafsir yang berorientasi fiqh. Penelitian ini menggunakan metode kajian pustaka untuk memotret metode-metode tafsir yang menghasilkan konsekuensi hukum dalam masyarakat Islam. Pengumpulan data dilakukan dengan menelaah sumber primer dan sekunder dalam mendukung kajian tersebut. Hasil telaah dan penelitian menemukan latar belakang muncul dan berkembangnya corak penafsiran fiqih serta metode yang digunakan dalam penafsiran yang bercorak fiqih. Tafsir yang bercorak fiqih adalah tafsir yang terbilang tua, mengingat corak tafsir ini telah ada seiring dengan pertumbuhan tafsir itu sendiri. Tafsir fiqih adalah tafsir yang berorientasi pada pemahaman ayat-ayat hukum dalam Alquran. Tafsir ini lahir dari pemahaman fiqhiyah para fuqaha ketika mereka menafsirkan Alquran dengan menggunakan pendekatan fiqih, sehingga nuansa fiqih sangat terasa di dalamnya.
\end{abstract}

\section{Kata Kunci: Kitab, Manhaj, Tafsir, dan Fiqh.}

\section{A. PENDAHULUAN}

Alquran merupakan firman Allah (verbum dei, kalām Allah) yang diwahyukan kepada Nabi Muhammad saw. melalui Rūh al-Amīn, malaikat Jibril untuk dijadikan sebagai pedoman hidup (way of life) bagi makhluk-makhluk-Nya di setiap ruang dan waktu. Alquran juga telah memperkenalkan dirinya sebagai kitab petunjuk bagi umat manusia (QS. Al-Baqarah [2]: 185), yang akan mengantarkan dan mengarahkan mereka kepada jalan yang paling lurus (QS. Al-Isra' [17]: 9), ${ }^{1}$ serta Allah menjamin keotentikannya sepanjang masa (QS. Al-Hijr [15]: 9). Hukumhukumnya berlaku sepanjang kehidupan manusia, tidak bersifat temporal dan statis, tetapi

\footnotetext{
${ }^{1}$ Muhammad Arkoun, Berbagai Pembacaan Al-Qur'an, ed. by Machasin (Jakarta: INIS, 1997)., h. 9.
} 
berlaku untuk semua zaman, semua masa, dan setiap generasi. Hal ini, menurut Thabathaba'i begitu juga Yusuf Qardawi, ${ }^{2}$ merupakan sebagian dari kekhususan yang dimiliki oleh Alquran.

Jika ditelusuri perkembangan tafsir Alquran sejak dulu sampai sekarang, akan ditemukan bahwa dalam garis besarnya, penafsiran Alquran dilakukan melalui empat cara (metode) yaitu: ijmali (global), tahlili (analitis), muqarin (perbandingan), dan maudhu'i (tematik). ${ }^{3}$ Lahirnya metode-metode tafsir ini, nampaknya lebih banyak disebabkan oleh tuntutan perkembangan zaman yang selalu dinamis. Dalam perkembangannya, metode-metode penafsiran tersebut menggunakan dua bentuk penafsiran yaitu, al-ma'tsūr (penafsiran yang disandarkan pada riwayat) dan al-ra'yi (penafsiran yang banyak menggunakan ijtihad/akal), dengan berbagai muatan corak yang melingkupinya, seperti lughawi, fiqh, tasawuf, falsafi, 'ilmi, adabi ijtima'i, dan lain-lain. ${ }^{4}$

Pada abad ke II H. sampai abad ke III H. corak penafsiran fiqih mendominasi penafsiran Alquran. ${ }^{5}$ Terutama, ketika muncul para imam mujtahid (baca fuqaha) yang mendorong munculnya mazhab-mazhab di bidang fiqih. Setiap golongan berusaha membuktikan kebenaran pendapatnya berdasarkan penafsiran-penafsiran terhadap ayat-ayat hukum. ${ }^{6}$ Pengaruh corak penafsiran fiqih ini, menurut penelitian Howard M. Fadersipiel, juga mewarnai penafsiran di Nusantara. ${ }^{7}$ Tentunya tidak mengherankan jika corak penafsiran fiqih muncul, sebab kebutuhan umat terhadap hukum yang mengatur seluruh segi kehidupan umat terasa sangat vital.

Alquran sendiri sebagai sumber utama ajaran Islam mengandung serangkaian pengetahuan tentang akidah, hukum perundang-undangan yang mengatur sisi kehidupan. Alquran juga berisi perskripsi-perskripsi tentang hukum peribadatan dan sosial. Oleh para fuqaha

2 Muhammad Husein Thabathaba'i, Al-Qur'an Fi Al-Islam Diterjemahkan Dengan Judul Memahami Esensi Al-Qur'an, ed. by Idrus Alkaf, III (Jakarta: Lentera, 2003)., h. 62. Lihat Yusuf Qardawi, Kaifa Nata'amal Ma'a Al-Qur'an Diterjemahkan Dengan Judul Bagaimana Berinteraksi Dengan Al-Qur'an, ed. by Kathur Suhardi (Jakarta: Pustaka Al-Kautsar, 2000)., h. 56.

${ }^{3}$ Nasaruddin Baidan, Metodologi Penafsiran Al-Qur'an, I (Yogyakarta: Pustaka Pelajar, 1998)., h. 3.

${ }^{4}$ Baidan., h. 4-6.

5 Ahmad Al-Syirbashi, Sejarah Tafsir Al-Qur'an, III (Jakarta: Pustaka Firdaus, 1994)., h. 71-89. Pada periode perkembangan tafsir, abad ke-II sampai abad ke-III H. yaitu ketika hadis-hadis telah menyebar ke berbagai wilayah, periode ini disebut periode kedua dalam periodesasi perkembangan tafsir-yang oleh Departemen Agama disebut sebagai periode mutaakhirin - , periode ini ditandai dengan munculnya beragam corak penafsiran, termasuk corak fiqih terasa lebih kental karena sejak awal memang telah berkembang subur pada masa sahabat.

${ }^{6}$ M. Quraish Shihab, Membumikan Al-Qur'an; Fungsi Dan Peran Wahyu Dalam Kehidupan Masyarakat, XXV (Bandung: Mizan, 2003)., h. 72.

7 Howard M. Federspel, Kajian Al-Quran Di Indonesia; Dari Mahmud Yunus Hingga Quraish Shihab (Bandung: Mizan, 1996)., h. 6. 
aturan-aturan ini kemudian dikembangkan secara berangsur-angsur sehingga dikenal sebagai Hukum Islam. ${ }^{8}$

Berdasarkan latar belakang masalah di atas, maka pembahasan makalah ini akan dirumuskan ke dalam beberapa poin yaitu:

1. Bagaimana latar belakang muncul dan berkembangnya corak penafsiran fiqih?

2. Apa metode yang digunakan dalam penafsiran yang bercorak fiqih?

3. Kitab-kitab tafsir apa saja yang bercorak fiqih?

\section{B. PEMBAHASAN}

\section{Latar Belakang Corak Penafsiran Fiqih}

a. Pengertian Tafsir Berorientasi Fiqih

Kata fiqih berasal dari kata faqiha-yafqahu-fiqhan wa tafaqqaha al-syai' yang berarti mengerti atau faham akan sesuatu. ${ }^{9}$ Kata al-fiqhu berarti sesuatu yang menghubungkan kepada ilmu yang tersembunyi (ghāib) dengan ilmu yang nyata (syāhid), yaitu lebih khusus kepada pengetahuan. ${ }^{10}$ Kata ini, terutama, sering digunakan untuk menunjuk pada bidang ilmu hukum Islam atau syari'ah. ${ }^{11}$

Pada masa-masa awal, yaitu pada masa sahabat dan tabi'in, kata fiqih berarti semua yang dipahamkan dari nash-nash Alquran dan hadis, baik yang berhubungan dengan akidah, akhlak, maupun yang berhubungan dengan amalan praktis. Para fuqaha pada saat itu disebut qurra' yaitu orang-orang yang hafal terhadap Alquran dengan mengerti hukum-hukum yang termuat di dalamnya, sebagai sumber pokok dan utama bagi syari' at Islam. ${ }^{12}$

Pada masa selanjutnya, setelah daerah-daerah kekuasaan Islam bertambah luas serta bertambah banyak lapangan hukum Islam, maka terma fiqih lebih sering digunakan untuk menunjuk pada sekumpulan hukum syara' yang berhubungan dengan perbuatan, seperti hukum wajib, haram, anjuran, makruh, mubah; atau sesuatu perbuatan sah atau tidak; mencukupi atau tidak, dan sebagainya. ${ }^{13}$ Sehingga sejak masa ini, hukum-hukum tersebut merupakan bidang ilmu yang berdiri sendiri dan orang yang ahli dalam bidang fiqih disebut fāqih atau fuqaha.

${ }^{8}$ Montgomery Watt, Pengantar Studi Al-Qur'an (Richard Bell), I (Jakarta: Rajawali Press, 1991)., h. 56.

${ }^{9}$ Mahmud Yunus, Kamus Arab-Indonesia, I (Jakarta: Yayasan Penyelenggara Penterjemah/Penafsiran Al Qur'an, 1973)., h. 321.

${ }^{10}$ Raghib Al-Asfahani, Al-Mufradat Fi Gharib Al-Qur'an (Beirut: Dar al-Ma'rifah, 2001)., h. 385.

11 Al-Asfahani., h. 386.

12 Ahmad Hanafi, Pengantar Dan Sejarah Hukum Islam, VII (Jakarta: Bulan Bintang, 1995)., h. 183.

${ }^{13}$ Hanafi., h. 11. 
Tafsir fiqih biasa juga disebut tafsir Ahkam yaitu corak tafsir yang berorientasi kepada fiqih atau pemahaman terhadap ayat-ayat hukum dalam Alquran. ${ }^{14}$ Menurut Khalil Muhyī al-Din al-Mīsi dalam muqaddimah kitab Jami' li Ahkam Al-Qur'an, bahwa yang dimaksud dengan tafsir fiqih adalah menetapkan hukum-hukum syari'ah dari ayat-ayat Alquran, dan dengan tidak bermaksud meninggalkan semua makna yang bermanfaat dari Alquran. ${ }^{15}$ Berbeda dengan corak tafsir yang lain, seperti tafsir 'ilmi dan tafsir falsafi, keberadaan tafsir fiqih diterima hampir seluruh lapisan mufassir.

b. Sejarah Muncul dan Berkembangnya Penafsiran Bercorak Fiqih

Dalam perkembangan tafsir, keberadaan tafsir bercorak fiqih berusia sudah sangat tua, sebab kelahirannya bersamaan dengan kelahiran tafsir itu sendiri. ${ }^{16}$ Seperti telah disebutkan sebelumnya, pada masa Nabi dan sahabat, tafsir fiqih ini telah ada. Corak tafsir yang mewarnai penafsiran para sahabat didominasi oleh corak penafsiran fiqih. Hal itu dapat dilihat dari fuqaha sahabat sendiri, antara lain Umar bin Khattab, Ibnu Mas'ud, Ali bin Abi Thalib, dan lain-lain. ${ }^{17}$ Menurut Abdullah Abu al-Su'ud Badr, hal ini sangat logis, mengingat kebutuhan zaman saat itu menuntut untuk membentuk gerakan menafsirkan Alquran dengan corak fiqih. ${ }^{18}$

Diturunkannya Alquran, menurut al-Dzahabi, meliputi ayat-ayat yang mengundung hukum-hukum fiqhiyah yang bertujuan untuk kemaslahatan hamba dalam kehidupan dunia dan akhirat. ${ }^{19}$ Pemahaman sahabat di masa Nabi saw. terhadap Alquran, menurut al-Dzahabi, lebih cenderung kepada "naluri kearaban", ${ }^{20}$ yaitu dengan menggunakan pendekatan kultural untuk memahami maksud sebuah ayat. Dan jika mengalami kesulitan dalam memahaminya, mereka kembali kepada Nabi saw. dan beliau pun lalu menjelaskannya kepada mereka. ${ }^{21}$

Setelah Nabi saw. wafat, para sahabat diperhadapkan pada situasi yang berbeda dari sebelumnya, yaitu ketika Nabi saw. masih berada di antara mereka. Berbagai persoalan baru

${ }^{14}$ Abd. Aziz Dahlan, Ensiklopedi Hukum Islam Jilid V, VI (Jakarta: Ichtiar Baru Van Hoeve)., h. 1736. Lihat juga Ahmad Izzan, Metodologi Tafsir (Bandung: Tafakur, 2007)., h. 206.

${ }^{15}$ Abi Abdillah Muhammad bin Ahmad al-Ansharī Al-Qurthubī, Jami' Li Ahkam Al-Qur'an Jilid I (Beirut: Dar al-Fikr, 1993)., h. 7.

${ }^{16}$ Izzan., h. 206.

17 Abdullah Abu al-Su'ud Badr, Tafsir Umm Al-Mukminin 'Aisyah Radhiyallahu Anha, ed. by M. Syamsuddin (Jakarta: Darul Falah, 2000), h. 35.

${ }^{18}$ Badr., h. 35-36.

19 Muhammad Husain Al-Dzahabi, Al-Tafsir Wa Al-Mufassirun Jilid III, I (Kairo: Dar al-Kutub alHaditsah, 1962)., h. 98.

${ }^{20}$ Al-Dzahabi., h. 98. 516.

${ }^{21}$ Manna Al-Qaththan, Mabahis Fi 'Ulum Al-Qur'an, VIII (Bogor: Pustaka Litera AntarNusa, 2004)., h. 
muncul dan menghendaki ketetapan hukum berdasarkan syariat. Dalam menghadapi situasi ini, para fuqaha sahabat kemudian kembali kepada Alquran dan mencoba menggali istinbath hukum berdasarkan Alquran terhadap persoalan tersebut. Dalam usaha itu, tidak jarang di antara mereka terjadi perselisihan pendapat terhadap sebuah persoalan, sehingga istinbath hukum yang mereka peroleh pun berbeda-beda. $^{22}$

Dari perbedaan penafsiran para sahabat itu, kemudian menjadi awal dari permulaan munculnya perbedaan pendapat pada masa selanjutnya di bidang fiqih dalam memahami ayatayat yang mengandung hukum.

Ketika masa awal pembentukan mazhab di bidang fiqih, yaitu pada abad ke II dan ke III H. dikenal dalam sejarah hukum Islam sebagai fase pembinaan dan pembentukan, disebut juga sebagai masa keemasan. Fase keemasan ini ditandai dengan berkembang pesatnya gerak ijtihad. Hal ini disebabkan beberapa faktor yaitu, a) meluasnya daerah kekuasaan Islam; b) pengaruh dari karya-karya sebelumnya; dan c) munculnya tokoh-tokoh mujtahid yang dijadikan sebagai imam mazhab. ${ }^{23}$

Pada masa ini, muncul para imam mazhab, seperti imam khamsah (Imam Abu Hanifah, Imam Malik, Imam Syafi'i, Imam Ahmad bin Hanbal, dan Imam Ja'far al-Shadiq) yang penganutnya masih terlihat hingga sekarang. Ketika daerah-daerah kekuasaan Islam semakin meluas, banyak pertanyaan menyangkut berbagai persoalan baru meminta kepastian hukum yang tidak ada preseden sebelumnya. Dalam keadaan ini, setiap imam mazhab berusaha mencari jawaban dari Alquran, sunnah, dan sumber-sumber lain yang sesuai kaidah universal. Kadang antar mereka terdapat kesepakatan ijtihad, terkadang pula terdapat perbedaan pendapat. Namun, perbedaan itu tidak menyebabkan fanatisme mazhab. Mereka masih menerima kemungkinan adanya pendapat yang benar dari imam yang lain. Sikap toleran ini terlihat, misalnya dari

${ }^{22}$ Al-Qaththan., h. 516., lihat pula Dahlan., h. 1736., lihat pula Misalnya perbedaan Umar bin Khattab dan Ali bin Abi Thalib ketika memahami ayat tentang 'iddah wanita hamil yang ditinggal mati suaminya. Perbedaan ini didasarkan pada perbedaan pandangan tentang maksud dua ayat, yaitu QS. Al-Baqarah/2: 234, tentang 'iddah wanita yang ditinggal mati suaminya adalah empat bulan sepuluh hari; dan QS. Al-Thalaq/65: 4, tentang 'iddah wanita hamil adalah melahirkan. Menurut Umar ayat pertama bersifat umum, mencakup wanita hamil ataupun wanita yang tidak hamil. Ia berpendapat bahwa ayat pertama dikhususkan dengan ayat kedua. Berdasarkan itu, Umar berpendapat bahwa 'iddah wanita hamil yang ditinggal mati suaminya adalah melahirkan. Sedangkan Ali berpendapat bahwa kedua ayat itu saling mengkhususkan, karena itu kedua ayat tersebut harus diamalkan. Sehingga ia berpendapat bahwa masa 'iddah wanita hamil yang ditinggal mati suaminya adalah masa terpanjang dari dua masa 'iddah itu.

${ }^{23}$ Hanafi., h. 198. 
pernyataan al-Syafi'i dan Ahmad bin Hanbal, "Jika hadis itu sahih maka itulah pendapatku" atau al-Syafi'i pernah berkata,'Dalam bidang fiqih, Abu Hanifah adalah ahlinya". ${ }^{24}$

Setelah masa imam mazhab, sikap taklid dan fanatisme mazhab melanda para pengikut suatu mazhab. Pada masa ini, sikap para pengikut imam hanya terfokos pada penjelasan dan pembelaan mazhab mereka, sehingga hal ini sangat mempengaruhi penafsiran mereka terhadap Alquran. Sebagai akibatnya, muncul tafsir fiqih yang khusus membawa ayat-ayat hukum dalam Alquran kepada pemahaman fiqhiyah. ${ }^{25}$

Demikianlah seterusnya hingga tiba masa pemurnian, sampai sekarang. Upaya para ulama untuk memberantas taklid buta dan kejumudan serta membuka kembali pintu ijtihad pada masa kebangkitan, telah melapangkan jalan bagi ulama pada masa ini hingga sekarang, untuk menggali kembali kandungan ayat-ayat hukum dari Alquran. ${ }^{26}$

\section{Metode Penafsiran Bercorak Fikih Fiqih}

Para ulama fiqih dan ushul fiqih mendefinisikan tafsir dengan menghilangkan kesamaran arti suatu nash. ${ }^{27}$ Dengan tafsir dapat diketahui dengan jelas makna yang dikehendaki oleh pemilik redaksi (al-Syari', Allah SWT) terhadap suatu nash. Menurut mereka, tafsir merupakan salah satu macam penjelasan terhadap ayat-ayat Alquran yang tidak jelas makna yang dikehendaki oleh al-Syari', yang berkenaan dengan perbuatan manusia. ${ }^{28}$

Ketidak-jelasan yang dimaksud dalam hal ini adalah redaksi ayat yang sifatnya global tanpa ada penjelasan mengenai rincian dan teknis pelaksanaannya. Hukum yang dikandung oleh ayat-ayat tersebut tidak dapat diterapkan sebagai suatu hukum yang berlaku dalam masyarakat tanpa ada penafsiran.

Para fuqaha dan ulama tafsir sepakat menyatakan bahwa apabila ayat-ayat yang mengandung makna yang kabur atau samar itu ditafsirkan dengan ayat yang lain atau dengan

\footnotetext{
${ }^{24}$ Dahlan., h. 137.

25 Al-Qaththan., h. 517.

${ }^{26}$ Muh. Ilham Usman, 'Pemikiran KH. Abdurrahman Wahid: Pesantren Fiqh-Sufistik Dan Pribumisasi Islam', Aqidah-Ta: Jurnal Ilmu Aqidah, 5.2 (2019)., h. 7-9.

27 Dahlan., h. 1733.

28 Ayat-ayat yang berkaitan dengan perbuatan manusia mukallaf lazim disebut dengan ayat-ayat hukum. Jumlah ayat-ayat yang berkaitan dengan hukum menurut Abd. Wahab Khallaf, hanya berkisar 5,8 \% dari keseluruhan jumlah ayat Alquran, yaitu kurang lebih 360-an ayat sedangkan menurut sebagian ulama, jumlah ayat hukum dalam Alquran sekitar 500 ayat. Lihat Muhammad Ibrahim Jannati, Belajar Mudah 'Ulum Al-Qu'an; Studi Khazanah Ilmu Al-Qur'an, ed. by Sukardi, I (Jakarta: Lentera, 2002)., h. 46.
} 
hadis Nabi saw., maka ayat-ayat tersebut telah keluar dari ruang lingkup ayat yang mengandung kekaburan dengan adanya nash lain yang menafsirkannya. ${ }^{29}$

Para fuqaha menganggap bahwa tafsir tidak ada lagi setelah Nabi saw. wafat. Adapun tafsir yang dilakukan sahabat dan generasi sesudahnya hanya menggunakan tafsir yang sudah ada pada masa Nabi saw., yaitu Alquran dan hadis. Kedudukan nalar (al-ra'yu) dalam tafsir yang dilakukan setelah Nabi saw., menurut kebanyakan mereka, tidak terhindar dari ihtimāl (bisa benar, bisa salah). Oleh karena itu, nash-nash Alquran yang ditafsirkan dengan nalar tidak dapat dipandang sebagai nash yang telah sirna kesamarannya. Dari sini,_- seperti halnya ulama tafsir-para fuqaha membagi tafsir dengan nalar (al-ra'yu) ke dalam tafsir mahmudah (yang terpuji) dan tafsir madzmumah (yang tecela). ${ }^{30}$

Alquran sebagai sumber paling otentik guna mengetahui hukum-hukum ilahi, tidak ada perbedaan pandangan antara ulama, baik Sunni dan Syi'ah. ${ }^{31}$ Hanya saja, dalam memanfaatkan sumber ini tentunya membutuhkan pengetahuan dan persyaratan yang memadai untuk mendeduksikan berbagai hukum dari Alquran. Tolok ukur dan kriteria dari setiap ulama, terutama imam-imam dari kedua golongan di atas, berbeda-beda. Dari sini, metode yang digunakan oleh para ulama sejak masa sahabat hingga para imam mazhab pun berbeda-beda.

Secara umum, metode yang digunakan para fuqaha untuk menafsirkan Alquran adalah: 1) menafsirkan ayat dengan ayat; 2) menafsirkan ayat Alquran melalui riwayat (hadis atau sunnah); 3) menafsirkan Alquran dengan menggunakan kaedah-kaedah universal (kulliyah fiqhiyah) dari Alquran dan Sunnah; dan 4) menafsirkan Alquran dengan prinsip-prinsip ijtihad (aqliyah). ${ }^{32}$

Penerapan metode ini, berbeda di kalangan para fuqaha, sehingga melahirkan perbedaan pemahaman dari deduksi hukum yang dihasilkan. Misalnya perbedaan penafsiran terhadap QS. Al-Baqarah/2: 228:

و المطلقت يتربصن بافسهن ثلثة قرؤء و لا يحل لهن ان يكتمن م خلق الله في ارحمهن ان كن يؤمن بالله و اليوم الاخر ... Terjemahnya:

“Wanita-wanita yang ditalak handaklah menahan diri (menunggu) tiga kali quru'..”.

${ }^{29}$ Dahlan., h. 1735.

${ }^{30}$ Dahlan., h. 1736.

31 Jannati., h. 53.

${ }^{32}$ Umar Shihab, Kontekstualitas Al-Qur'an; Kajian Tematik Atas Ayat-Ayat Hukum Dalam Al-Qur'an, III (Jakarta: Penamadina, 2005)., h. 220 dan 257. 
Menurut imam Syafi'i kata quru’ berarti suci, sedangkan menurut imam Abu Hanifah berarti haid. ${ }^{33}$ Imam syafi'i mendasarkan pendapatnya pada kaidah bahasa Arab bahwa setiap bilangan muannas, maka kata di belakangnya harus mudzakkar; kata quru' jika berbentuk mudzakkar berarti suci. Sedangkan kata haid adalah muannāś. Adapun imam Abu Hanifah, selanjutnya mengemukakan argumen bahwa hikmah ditetapkannya iddah adalah untuk mengetahui apakah rahim berisi atau tidak. ${ }^{34}$

Contoh lainnya, penafsiran QS. Al-Baqarah/2: 226:

$$
\text { للذين يؤلون من نساهم تربص اربعة اثهر فان فاءو فان الله غفور رحيم }
$$

Terjemahnya:

Kepada orang-orang yang meng-ilaa' isterinya diberi tangguh empat bulan (lamanya). Kemudian jika mereka kembali (kepada isterinya), Maka Sesungguhnya Allah Maha Pengampun lagi Maha Penyayang.

Kata ya'lūna berasal dari kata $\bar{\imath} l \bar{a}$ ' yang berarti seseorang yang bersumpah untuk tidak menggauli istrinya. Dari pengertian bahasa, tidak terdapat perbedaan pendapat di kalangan ulama, tetapi istinbath hukum berdasarkan penafsiran ayat tersebut, banyak menimbulkan pemahaman yang berbeda. Misalnya imam Malik dan Abu Hanifah berpendapat bahwa istri yang telah digauli dan yang belum digauli, kedudukannya sama dalam berlakunya $\bar{\imath} l \bar{a}$ '. Dan imam Malik menambahkan syarat bahwa $\bar{l} l \bar{a}$ ' hanya sah terhadap istri yang sudah baligh. Begitu juga mengenai batas berlakunya. Imam Malik, Syafi'i, dan Ahmad menyatakan bahwa ìlā' berlaku apabila melebihi waktu empat bulan, sedangkan Abu Hanifah menyatakan hanya empat bulan saja. ${ }^{35}$ Timbulnya kontroversi penafsiran itu, karena dalam ayat hanya disebutkan limit waktu menunggu, sementara masa $\bar{\imath} \bar{l}$ ' tidak ditegaskan.

\section{Kitab-Kitab Tafsir Bercorak Fiqih}

Selama berabad-abad lamanya, para fuqaha besar Islam telah bersungguh-sungguh melakukan riset terus-menerus ihwal ayat-ayat Ahkām dan hingga kini di antara berbagai hasil jerih payah mereka itu masih bisa diperoleh. Setelah para imam mazhab, kecenderungan untuk

${ }^{33}$ Pendapat al-Syafi'i sejalan dengan pendapat 'Aisyah ketika menafsirkan ayat ini, yaitu dengan berdasar bahwa talak hanya bisa dilakukan pada saat suci, dan masa iddah bagi istri yang tertalak adalah masa suci pertama dalam perhitungan yang disyariatkan. Sedangkan pendapat Abu Hanifah sejalan dengan pendapat Umar bin Khattab, Ali bin Abi Thalib, dan Ibnu mas'ud. Lihat Badr., h. 62.

${ }^{34}$ Umar Shihab., h. 269-270.

${ }^{35}$ Umar Shihab., h. 270-271. 
bermazhab memunculkan corak tafsir fiqih yang mengarah kepada pembelaan suatu mazhab, baik itu dari kalangan sunni maupun syiah.

Untuk lebih jelasnya, berikut ini akan disebutkan berbagai kitab tafsir yang bercorak fiqih menurut mazhab masing-masing.

1. Karya-karya Hanafiyah, di antaranya:

a. Ahkām Al-Qur'ān, oleh 'Ali bin Hajar bin Sa'di al-Maruzi al-Khurasani (w. 244 $\mathrm{H} / 858 \mathrm{M})$.

b. Ayat al-Ahkām, disusun oleh 'Ali bin Musa (w. 305 H/917 M).

c. Ahkām Al-Qur'ān, oleh Ahmad bin Muhammad al-Azdi al-Thahawi al-Mishri (w. $307 \mathrm{H} / 933 \mathrm{M})$.

d. Syarh Ahkām Al-Qur'ān, di susun oleh Ahmad bin 'Ali al-Razi, dikenal sebagai alJashshash (w. 370 H/980 M).

2. Karya-karya Malikiyah, antara lain:

a. Ahkām Al-Qur'ān, oleh Ahmad bin Mu'dhal (w. 240 H/854 M).

b. Ahkām Al-Qur'ān, oleh Muhammad bin 'Abdullah, dikenal sebagai Ibn al-Hakam (w. $268 \mathrm{H} / 881 \mathrm{M})$.

c. Ayat Ahkām, oleh Isma'il bin Ishaq al-Azdi (w. 282 H/895 M).

d. Ayat al-Ahkām, oleh al-Qasim bin Ashbagh al-Quthubi al-Andalusi (w. 304 H/916 $\mathrm{M})$.

e. Al-Jāmi li Ahkām Al-Qur'ān, oleh Abu 'Abdillah Muhammad bin Ahmad al-Anshari al-Qurthubi (w. 671 H/1272 M).

3. Karya-karya Syafi'iyah, di antaranya:

a. Ahkām Al-Qur'ān, oleh Muhammad bin Idris al-Syafi'i (204 H/819 M).

b. Ahkām Al-Qur'ān, oleh Abu al-Hasan al-Thibri, lebih dikenal dengan al-Kiya alHarasi (w. $504 \mathrm{H} / 1058 \mathrm{M}$ ).

c. Al-Qaul al-Wajizz fi Ahkām al-Kitāb al-'Aziz, oleh Syihab al-Din Abu al-'Abbas Ahmad binYusuf bin al-Halabi, yang dikenal dengan al-Samin (w. 756 H/1355 M).

d. Al-Iklil fi Istinbath al-Tanzīl, oleh Jalal al-Din al-Suyuthi (w. 911 H/1505 M).

e. Manār al-Islam fi Syarh Ayat al-Ahkām, oleh Ahmad Zayni Dahlan al-Hasani, seorang mufti Mekah (w. 1304 H/1886 M).

4. Karya-karya Hanbaliyah, di antaranya: 
a. Ayat al-Ahkām, disusun oleh Qadhi Abu Ya'la al-Kabir (w. 458 H/1066 M).

b. Ayat al-Ahkām, oleh Muhammad bin Abu Bakr al-Dimasyqi al-Razi, dikenal dengan Ibn al-Qayyim al-Jauzi (w. 715 H/1305 M).

5. Karya-karya Syiah Iśna 'Asyariyah, antara lain:

a. Ayat al-Ahkām, disusun oleh Muhammad bin Sa'ib al-Kalbi (w. 146 H/763 M).

b. Tafsir al-Khamsini'at, oleh Muqatil bin Sulaiman al-Khurasani al-Balkhi (w. 150 $\mathrm{H} / 767 \mathrm{M})$.

c. Ahkām Al-Qur'ān, oleh Hisyam bin Muhammad bin Sa'ib al-Kilbi al-Kufi (w. 204 atau $206 \mathrm{H} / 819$ atau $821 \mathrm{M})$.

d. Kanz al-'Irfān fi Fiqh Al-Qur'ān, oleh Fadhil Miqdad bin 'Abdullah al-Suyuri alAsadi al-Hilli (w. 826 H/1423 M).

6. Karya-karya Syiah Zaidiyah, antara lain:

a. Syarh Ayat al-Ahkām, disusun oleh Yahya bin Hamzah al-Yamani (w. 749 H/1348 M)

b. Ayat al-Ahkām, oleh Ahmad bin Yahya al-Yamani (w. 840 H/1438 M).

c. Syarh Ayat al-Ahkām, oleh Muhammad bin Yahya Sha'di al-Yamani (w. 957 H/1550 M).

\section{Kelebihan dan Kekurangan Tafsir Fiqih}

Sebagai salah satu nuansa (corak) dalam penafsiran, tafsir yang bernuansa fiqih telah terbukti sangat lama dikenal dalam ranah penafsiran Alquran. Para fuqaha telah memusatkan perhatian dan riset mereka dalam menggali kandungan hukum dari Alquran. Kerja keras mereka dalam mengurai makna-makna yang terkandung dalam sebuah ayat tidak terlepas dari metode yang mereka gunakan ketika memahami ayat-ayat Alquran. Namun begitu, sebagaimana corak penafsiran yang lain, corak penafsiran fiqih tentunya juga memiliki kelebihan dan kekurangan di dalamnya.

1. Kelebihan tafsir bercorak fiqih, antara lain:

a. Penafsiran terhadap ayat Ahkām dalam Alquran dengan menggunakan pendekatan fiqhiyah (tafsir fiqih), memungkinkan untuk terhindar dari fanatisme terhadap suatu mazhab atau setidaknya mereda. ${ }^{36}$

\footnotetext{
${ }^{36}$ Al-Qaththan., h. 517.
} 
b. Perbedaan istinbath hukum dalam menafsirkan ayat Alquran yang mengandung hukum, memberikan peluang yang lebih besar untuk menerapkan hukum syariat.

c. Keaneka-ragaman penafsiran hukum yang dikandung sebuah ayat, selain merupakan kekayaan (khazanah) hukum Islam, juga menunjukkan bahwa nash Alquran senantiasa memberi petunjuk, bukan sebagai penghalang. ${ }^{37}$

2. Kekurangan tafsir bercorak fiqih, antara lain:

a. Penafsiran Alquran yang khusus membahas ayat-ayat hukum dalam Alquran, memungkinkan untuk memunculkan fanatisme terhadap suatu mazhab, dan pembelaan yang berlebihan terhadap suatu mazhab yang terkadang membawa ayatayat Alquran kepada makna yang "lemah" dan "jauh". 38

b. Pembatasan penafsiran terhadap ayat-ayat hukum (ayat al-ahkām) dalam Alquran, menjadikan sifat universal dan komprehensif Alquran menjadi terasa parsial.

c. Penafsiran khusus terhadap ayat-ayat ahkām (tafsir fiqih), menjadikan tafsir ini sifatnya selektif, yang hanya mengarah kepada pemahaman material ayat dan terkadang mengenyampingkan pemahaman spiritual. ${ }^{39}$

\section{PENUTUP}

\section{Kesimpulan}

Tafsir yang bercorak fiqih adalah tafsir yang terbilang tua, mengingat corak tafsir ini telah ada seiring dengan pertumbuhan tafsir itu sendiri. Tafsir fiqih adalah tafsir yang berorientasi pada pemahaman ayat-ayat hukum dalam Alquran. Tafsir ini lahir dari pemahaman fiqhiyah para fuqaha ketika mereka menafsirkan Alquran dengan menggunakan pendekatan fiqih, sehingga nuansa fiqih sangat terasa di dalamnya. Adapun metode yang mereka gunakan, secara umum, a) menafsirkan ayat dengan ayat; b) menafsirkan ayat Alquran melalui riwayat (hadis atau sunnah); c) menafsirkan Alquran dengan menggunakan kaedah-kaedah universal (kulliyah fiqhiyah) dari Alquran dan Sunnah; dan d) menafsirkan Alquran dengan prinsip-prinsip ijtihad (aqliyah). Seperti halnya corak-corak tafsir yang lain, corak tafsir ini juga mempunyai kelebihan dan kekurangan yang melingkupinya.

\footnotetext{
${ }^{37}$ Umar Shihab., h. 272.

38 Al-Qaththan., h. 517.

39 Jannati., h. 77-78.
} 


\section{DAFTAR PUSTAKA}

Al-Asfahani, Raghib, Al-Mufradat Fi Gharīb Al-Qur'ān. Beirut: Dar al-Ma'rifah, 2001.

Al-Dzahabi, Muhammad Husain, Al-Tafsir Wa Al-Mufassirun Jilid III, I. Kairo: Dar al-Kutub alHaditsah, 1962.

Al-Qaththan, Manna, Mabahis Fi 'Ulum Al-Qur'An, VIII. Bogor: Pustaka Litera AntarNusa, 2004.

Al-Qurthubī, Abi Abdillah Muhammad bin Ahmad al-Ansharī, Jami' Li Ahkam Al-Qur'an Jilid I. Beirut: Dar al-Fikr, 1993.

Al-Syirbashi, Ahmad, Sejarah Tafsir Al-Qur'an, III. Jakarta: Pustaka Firdaus, 1994.

Arkoun, Muhammad, Berbagai Pembacaan Al-Qur'an, ed. by Machasin. Jakarta: INIS, 1997.

Badr, Abdullah Abu al-Su'ud, Tafsir Umm Al-Mukminin 'Aisyah Radhiyallahu Anha, ed. by M. Syamsuddin. Jakarta: Darul Falah, 2000.

Baidan, Nasaruddin, Metodologi Penafsiran Al-Qur'an, I. Yogyakarta: Pustaka Pelajar, 1998.

Dahlan, Abd. Aziz, Ensiklopedi Hukum Islam Jilid V, VI. Jakarta: Ichtiar Baru Van Hoeve.

Federspel, Howard M., Kajian Al-Quran Di Indonesia; Dari Mahmud Yunus Hingga Quraish Shihab. Bandung: Mizan, 1996.

Hanafi, Ahmad, Pengantar Dan Sejarah Hukum Islam, VII. Jakarta: Bulan Bintang, 1995.

Izzan, Ahmad, Metodologi Tafsir. Bandung: Tafakur, 2007.

Jannati, Muhammad Ibrahim, Belajar Mudah 'Ulum Al-Qu'an; Studi Khazanah Ilmu Al-Qur'an, ed. by Sukardi, I. Jakarta: Lentera, 2002.

Qardawi, Yusuf, Kaifa Nata'amal Ma'a Al-Qur'ān Diterjemahkan Dengan Judul Bagaimana Berinteraksi Dengan Al-Qur'an, ed. by Kathur Suhardi. Jakarta: Pustaka Al-Kautsar, 2000.

Shihab, M. Quraish, Membumikan Al-Qur'an; Fungsi Dan Peran Wahyu Dalam Kehidupan Masyarakat, XXV. Bandung: Mizan, 2003.

Shihab, Umar, Kontekstualitas Al-Qur'an; Kajian Tematik Atas Ayat-Ayat Hukum Dalam AlQur'an, III. Jakarta: Penamadina, 2005.

Thabathab'i, Muhammad Husein, Al-Qur'an Fi Al-Islam Diterjemahkan Dengan Judul Memahami Esensi Al-Qur'an, ed. by Idrus Alkaf, III. Jakarta: Lentera, 2003.

Usman, Muh. Ilham, 'Pemikiran KH. Abdurrahman Wahid: Pesantren Fiqh-Sufistik Dan 
Pribumisasi Islam', Aqidah-Ta: Jurnal Ilmu Aqidah, 5.2. 2019.

Watt, Montgomery, Pengantar Studi Al-Qur'an (Richard Bell), I. Jakarta: Rajawali Press, 1991.

Yunus, Mahmud, Kamus Arab-Indonesia, I. Jakarta: Yayasan Penyelenggara Penterjemah/Penafsiran Al Qur'an, 1973. 